\title{
Learning Multimedia Based on RPG Maker MV Material for Circumference and Area of Flat Shapes for Elementary School Students
}

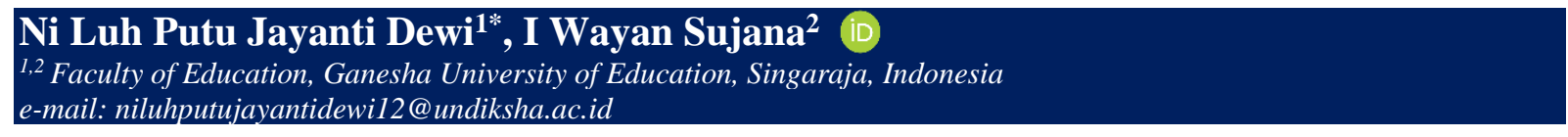

\section{A R T I CLE I N F O}

Article history:

Received May 13, 2021

Revised May 17, 2021

Accepted June 10, 2021

Available online August 25, 2021

Kata Kunci:

Multimedia Pembelajaran, $R P G$

Maker MV, Matematika

Keywords:

Learning Multimedia, RPG

Maker MV, Mathematics

DOI:

https://dx.doi.org/10.23887/jet.v5 i2.34462

\begin{abstract}
A B S T R A K
Pelaksanaan pembelajaran selama pandemi Covid-19 menyebabkan siswa menjadi cepat jenuh serta bosan dan belum tersedia multimedia pembelajaran daring. Untuk mengatasi hal tersebut, dilakukan penelitian pengembangan dengan tujuan menghasilkan rancang bangun serta multimedia pembelajaran yang layak digunakan setelah melalui uji ahli materi, ahli media pembelajaran, ahli desain pembelajaran, uji coba perorangan dan uji coba kelompok kecil. Penelitian ini mengembangkan materi keliling dan luas bangun datar untuk siswa kelas IV SD yang berbasis RPG Maker MV dengan menggunakan model Hannafin and Peck. Jenis data yang digunakan adalah data kualitatif dan kuantitatif, dengan metode dan instrumen pengumpulan data yaitu angket. Metode dan teknik analisis data yang digunakan yaitu analisis deskriptif kualitatif dan deskriptif kuantitatif. Hasil dari penelitian pengembangan ini yaitu: 1) Dihasilkan rancang bangun multimedia pembelajaran berbasis RPG Maker MV materi keliling dan luas bangun datar pada siswa SD dengan menggunakan model Hannafin and Peck, 2) Kelayakan multimedia pembelajaran berbasis RPG Maker MV materi keliling dan luas bangun datar pada siswa SD yang meliputi: (a) Uji ahli materi memeroleh persentase $90 \%$ dengan kualifikasi sangat baik (sangat layak), (b) Uji ahli media pembelajaran memeroleh persentase 96,7\% dengan kualifikasi sangat baik (sangat layak), (c) Uji ahli desain pembelajaran memeroleh persentase 95\% dengan kualifikasi sangat baik (sangat layak), (d) Uji coba perorangan memperoleh persentase 96,7\% dengan kualifikasi sangat baik (sangat layak), (e) Uji coba kelompok kecil memeroleh persentase 95,6\% dengan kualifikasi sangat baik (sangat layak). Maka, dapat disimpulkan bahwa multimedia pembelajaran yang dihasilkan sangat layak untuk digunakan dalam proses pembelajaran.
\end{abstract}

\section{A B S T R A C T}

It is known that the implementation of learning during the Covid-19 pandemic causes students to become bored quickly and online learning multimedia is not yet available. To overcome this, development research is carried out to produce designs and learn multimedia that are suitable for use after going through the material expert test, learning media experts test, learning design experts test, individual trials, and small group trials. This research develops circumference and area of flat shapes for fourth-grade elementary school students based on RPG Maker MV by using the Hannafin and Peck model. The types of data used are qualitative and quantitative, with data collection methods and instruments namely questionnaires. Data analysis methods and techniques used are descriptive qualitative and descriptive quantitative analysis. The results of this development research are: 1) The design of learning multimedia based on RPG Maker MV is made for elementary students using the Hannafin and Peck model, 2) Feasibility of learning multimedia based on RPG Maker MV for circumference and area of flat shapes in elementary school students which include: (a) Material expert test get a percentage of $90 \%$ with very good qualifications (very feasible), (b) Learning media expert test get a percentage of $96.7 \%$ with very good qualifications (very feasible), (c) Learning design expert test get a percentage of 95\% with very good qualifications (very feasible), (d) The individual trials get a percentage of $96.7 \%$ with very good qualifications (very feasible), (e) The small group trial get a percentage of $95.6 \%$ with very good qualifications (very feasible). So it can be concluded that the resulting learning multimedia is very feasible to be used in the learning process.

This is an open access article under the CC BY-SA license.

Copyright $\left(C_{0} 2021\right.$ by Author. Published by Universitas Pendidikan Ganesha.

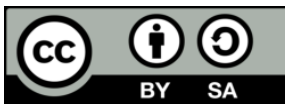

\section{INTRODUCTION}

The Covid-19 pandemic that hit Indonesia since March 2020 has greatly impacted the education sector in Indonesia (Handayani et al., 2020; Yulia, 2020). Learning that was originally carried out offline has now 
turned into online learning (Shaik Alavudeen et al., 2021; Wong et al., 2020). Following the circular letter of the minister of education and culture of the Republic of Indonesia number 4 of 2020 concerning the Implementation of Educational Policies in the Coronavirus Disease (Covid-19) Emergency Period, the learning process during the Covid-19 pandemic situation is carried out through online or distance learning. Based on the pre-research results at SD Negeri 3 Sesetan through observation, interviews with class IV-A teachers, and giving questionnaires to students, it was found that during online learning there were obstacles such as students felt bored because learning was carried out monotone, students do not focus on learning and students find it was difficult to understand math material because there are not enough appropriate learning media to use when online learning, teachers find it difficult to hold meetings with students through zoom meetings or google meet due to time constraints and limited quotas they have for learning and some students do not have a personal smartphone so they have to rely on their parent's smartphone to study. Distance learning has an impact on students such as students feeling bored studying at home, there are obstacles in distance learning due to lack of facilities for the teaching and learning process, students are not familiar with the distance learning process because students are accustomed to being at school and interacting with friends and teachers, distance learning affects students absorption, enthusiasm, and motivation to learn (Abidah et al., 2020; Adedoyin \& Soykan, 2020).

Learning media as a tool that can assist teachers in conveying and clarifying material, facilitate students in obtaining information, generate interest and motivation of students in learning (Kivunja, 2015; Saripudin et al., 2018; Shaik Alavudeen et al., 2021). E-learning tools are playing a crucial role during this pandemic because it aims to help instructors, schools and universities facilitate student learning process (Darmaji et al., 2019; Tere et al., 2020). Given the importance of the function of learning media as a tool to convey material, a tool to motivate and give information to students, a tool to manipulate objects, circumstances, or certain events in learning (Jogezai et al., 2021; Nugroho \& Iqbal Arrosyad, 2020). The urgency of the availability of online learning media is very important because if online learning media is not available properly of course it can affect online learning because of the lack of facilities for learning. In fact, in class IV-A the use of media for online learning has so far been limited to flat-shaped teaching aids that available at school and videos of learning materials that are sent to the WhatsApp group for class IV-A. According to the teacher, the learning media is less effective because the media in the form of teaching aids can only be used when doing zoom meetings or google meet with students, while the learning media in the form of videos sometimes do not have complete material. Obstacles encountered by teachers when they want to make their own learning media that are interesting, complete, and flexible to use during the online learning is that the teacher can not be able to use technology that exist (Dewi et al., 2019; Kivunja, 2015; Raja \& Nagasubramani, 2018).

Along with the development of science and technology now learning media has developed by utilizing the flexibility contained in computers to solve learning problems. Learning multimedia as one of the media that utilizes the flexibility of computers can certainly provide many benefits such as being able to combine video, audio, and graphic elements in the learning process (Indah Septiani et al., 2020; Ran et al., 2016). The learning using interactive multimedia had a significant effect on improving student learning outcomes and students had a positive attitude towards learning when using interactive multimedia (Daniels \& Gierl, 2017; Emerson et al., 2020). Some of the advantages of multimedia such as interesting and fun because it is presented according to student characteristics like being able to adjust colors, appearance, images, effects, animations and sounds so that it is not boring for users, and the commands used in multimedia are simple and users can actively choose the material menu or the existing questions (Daniels \& Gierl, 2017; Knoop-van Campen et al., 2020). Learning multimedia also has used to overcoming the limitations of space and time, clarifying the presentation of messages, preventing verbalism, overcoming students passive attitudes, making students more interactive, creative and active independently, and can transmit messages to be more constructive and interesting (Heo \& Toomey, 2020; Maria et al., 2019).

In the making of learning media that was several criteria must be considered, one of those is the analysis of student characteristics (Bal-Taştan et al., 2018; Ristanti \& Arianto, 2019). Elementary school-age children have an age range of 7 to 12 years, at that age the child's cognitive development is at the concrete operational stage where the child is mature enough to use logical thinking but is still fixated on physical objects (Burhaein, 2017; Juwantara, 2019). So that learning multimedia in this case serves as an object to help students understand the subject matter. Teachers should be able to create interesting and fun learning because of the characteristics of elementary school students who like to play, like to move, like to work in groups, and like to feel or do something directly (Majid et al., 2012; Manurung \& Panggabean, 2020). Due to the characteristics of students who still like to play and do things directly, but there are no learning multimedia that produces games that can be used directly and flexibly by students during online learning (Kassim \& Idris, 2018; Khamparia \& Pandey, 2017). So that the resulting learning multimedia does not only provide pictures, videos, materials, or questions like learning multimedia in general, but also has a story in it. In addition, this learning multimedia can also make students more interested and motivated to learn because it is done while playing games, so students do not get bored quickly. 
The development of learning multimedia based on RPG Maker MV is also based on several relevant studies. Previous research stated that multimedia learning can facilitate students in learning (Riyanto \& Gunarhadi, 2017; Rubini et al., 2018). Other research also states that learning media in the form of multimedia can improve student learning outcomes because students are more motivated in learning (Chen \& Li, 2011; Lauc et al., 2020). It can be concluded that learning multimedia can help students learn independently. The purpose of this development research is to provide solutions to the problems that have been described by: Designing and developing learning multimedia that can be used during online learning, Providing learning multimedia that is suitable for use after passing a feasibility test by experts (material experts, learning media experts, learning design experts) and students (individual trials, small group trials).

\section{METHOD}

The method used in this study is a research and development method, which aims to create and develop certain products by testing their validity and effectiveness (Pranopik, 2017; Sugiyono, 2019). The development research model used is the Hannafin and Peck model which consists of the needs assessment stage, the design stage, the development and implementation stage as well as the evaluation and revision process at each stage (Pratomo, 2015; Tegeh et al., 2014). The research procedure starts from the needs assessment stage which is carried out by instructional problem analysis, audience analysis, goal analysis, and instructional setting analysis. Then proceed with the design stage such as concept planning ideas for making learning multimedia which consists of determining software and hardware, making content outlines (making material, creating characters, determining game flow, determining game titles), making flowcharts, making storyboards, compiling RPP, as well as compiling product assessment instruments. Next is the development and implementation stage such as developing learning multimedia that begins with making the initial page or menu design, followed by the mapping process, databased using, eventing, testing, making compact disk (CD) designs and packing the file. The results of learning multimedia products that have been developed, then through a product feasibility test by experts, individual trials and small group trials to determine the feasibility of the product. The tests by the experts consisted of one material expert, media expert, and design expert. After the multimedia product is considered feasible by the experts, it is continued with individual trials and small group trials. Individual trials were carried out by three students grade IV-A at SD Negeri 3 Sesetan with the category of one student who had high learning outcomes, one student who had moderate learning outcomes and one student who had low learning outcomes. While the small group trial was carried out by nine students grade IV-A. The evaluation and revision process is carried out at each stage with the aimed to improving the learning multimedia so that it is in accordance with notes, suggestions and comments from expert and students in order to avoid errors and gets a perfect the final product.

Subjects in the development research of learning multimedia based on RPG Maker MV materials for circumference and area of flat shapes have gone through several stages of product feasibility testing using data collection methods and instruments in the form of a questionnaire. The questionnaire used in this study has gone through the consultation stage and has been approved by the mentor for use in data collection. The material expert questionnaire consists of three assessment aspects such as curriculum aspects, material presentation aspects, and evaluation aspects. In the learning media expert questionnaire, there are 15 statement items developed from the questionnaire owned by (Wardani \& Setyadi, 2020). The learning media expert questionnaire consists of two assessment aspects such as display aspect and the user aspect. In the learning design expert questionnaire, there are 10 statement items developed from the questionnaire owned by (Sholihah, 2019). The learning design expert questionnaire consists of three assessment aspects such as visualization aspects, curriculum aspects, and material aspects. In the individual test questionnaires and small group trials, there are 10 statement items developed from the questionnaire owned by (Wardani \& Setyadi, 2020). The individual trial questionnaire and the small group trial questionnaire consisted of two aspects such as the display aspect and the functional aspect. The entire questionnaire used in the product feasibility test was made using a Likert scale. The questionnaire grids for material experts, learning media experts, learning design experts, individual trials, and small group trials can be described as follows.

Table 1. Material Expert Questionnaire

\begin{tabular}{lllll}
\hline No & Aspect & Indicator & Items & Items Number \\
\hline & Curriculum & Basic competencies & 1 & \\
1. & Aspect & Indicator & 2 & 3 \\
& & Learning objectives & 3 & \\
2. & Material & Material Accuracy & 4 & 4 \\
\hline
\end{tabular}




\begin{tabular}{|c|c|c|c|c|}
\hline No & Aspect & Indicator & Items & Items Number \\
\hline \multirow{6}{*}{3.} & Presentation & Clarity of material description & 5 & \multirow{6}{*}{3} \\
\hline & \multirow[t]{2}{*}{ Aspects } & Ease of students in understanding the material & 6 & \\
\hline & & $\begin{array}{l}\text { The suitability material with students characteristics that } \\
\text { like to play }\end{array}$ & 7 & \\
\hline & & $\begin{array}{l}\text { The suitability of the questions with the objectives and } \\
\text { learning materials }\end{array}$ & 8 & \\
\hline & $\begin{array}{l}\text { Evaluation } \\
\text { Aspect }\end{array}$ & $\begin{array}{l}\text { The suitability of the level of difficulty of the questions } \\
\text { with the cognitive stage of students. }\end{array}$ & 9 & \\
\hline & & The suitability of the variety of questions & 10 & \\
\hline
\end{tabular}

Table 2. Learning Media Expert Questionnaire

\begin{tabular}{|c|c|c|c|c|}
\hline No & Musty & Indicator & Items & Items Number \\
\hline \multirow{8}{*}{1.} & \multirow{8}{*}{$\begin{array}{l}\text { Display } \\
\text { Aspect }\end{array}$} & Image attraction & 1 & \multirow{8}{*}{8} \\
\hline & & Interesting animation & 2 & \\
\hline & & Image suitability & 3 & \\
\hline & & Animation suitability & 4 & \\
\hline & & Readability of writing & 5 & \\
\hline & & Color variation compatibility & 6 & \\
\hline & & Design suitability & 7 & \\
\hline & & $\begin{array}{l}\text { The suitability of media with the student } \\
\text { characteristics }\end{array}$ & 8 & \\
\hline \multirow{7}{*}{2.} & \multirow{7}{*}{ User Aspect } & Clarity of form and game instructions & 9 & \multirow{7}{*}{7} \\
\hline & & Ease of use & 10 & \\
\hline & & Flexible in use & 11 & \\
\hline & & Interesting for students & 12 & \\
\hline & & Motivate students & 13 & \\
\hline & & Consists of games and learning & 14 & \\
\hline & & Have practice or questions & 15 & \\
\hline
\end{tabular}

(Wardani \& Setyadi, 2020) with research modifications.

Table 3. Learning Design Expert Questionnaire

\begin{tabular}{|c|c|c|c|c|}
\hline No & Musty & Indicator & Items & Items Number \\
\hline \multirow{5}{*}{1.} & \multirow{5}{*}{$\begin{array}{l}\text { Visualization } \\
\text { Aspect }\end{array}$} & Color Match & 1 & \multirow{5}{*}{5} \\
\hline & & Language compatibility & 2 & \\
\hline & & Image clarity & 3 & \\
\hline & & Animation clarity & 4 & \\
\hline & & Writing clarity & 5 & \\
\hline \multirow{3}{*}{2.} & \multirow{3}{*}{$\begin{array}{l}\text { Curriculum } \\
\text { Aspect }\end{array}$} & KD compatibility & 6 & \multirow{3}{*}{3} \\
\hline & & Indicator suitability & 7 & \\
\hline & & Suitability of learning objectives & 8 & \\
\hline \multirow{2}{*}{3.} & Material & The attractiveness of presenting material & 9 & \multirow{2}{*}{2} \\
\hline & Aspect & The suitability of the evaluation with the material & 10 & \\
\hline
\end{tabular}

(Sholihah, 2019) with researcher modifications.

Table 4. Individual Trial Questionnaire and Small Group Trial Questionnaire

\begin{tabular}{|c|c|c|c|c|}
\hline No & Aspect & Indicator & Item & Items Number \\
\hline \multirow{4}{*}{1.} & \multirow{4}{*}{$\begin{array}{l}\text { Display } \\
\text { Aspect }\end{array}$} & Attractive colors, text, images, and animations & 1 & \multirow{4}{*}{ 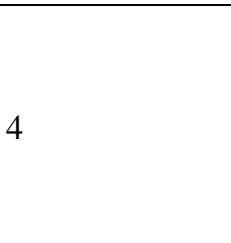 } \\
\hline & & Appropriate size animation, images, and text & 2 & \\
\hline & & $\begin{array}{l}\text { The suitability of the location of animation, images, } \\
\text { and text }\end{array}$ & 3 & \\
\hline & & $\begin{array}{l}\text { Ease of operating learning multimedia based on Role } \\
\text { Play Game (RPG) }\end{array}$ & 4 & \\
\hline \multirow{3}{*}{2.} & \multirow{3}{*}{$\begin{array}{l}\text { Functional } \\
\text { Aspect }\end{array}$} & Can provide learning facilities for students & 5 & \multirow{3}{*}{6} \\
\hline & & Can provide a means of practice for students & 6 & \\
\hline & & Can be used independently by students & 7 & \\
\hline
\end{tabular}




\begin{tabular}{|c|c|c|c|c|}
\hline No & Aspect & Indicator & Item & Items Number \\
\hline & & Can be used flexibly & 8 & \\
\hline & & Can explain the material & 9 & \\
\hline & & Can motivate students to learn & 10 & \\
\hline
\end{tabular}

(Wardani \& Setyadi, 2020) with researcher modifications.

After the questionnaire was assessed by experts and students, then the questionnaire was analyzed using qualitative descriptive analysis methods and quantitative descriptive analysis methods. This qualitative descriptive analysis method was used to process the data from the assessment results from material experts, learning media experts, learning design experts, individual trials, and small group trials obtained from a questionnaire in the form of notes, suggestions, and comments on learning multimedia based on RPG Maker MV which was developed. This quantitative descriptive analysis method was used to process data from the assessment results from material experts, learning media experts, learning design experts, individual trials, and small group trials obtained from a questionnaire in the form of scores using a Likert scale. After the percentage score is obtained, for decision making whether or not the learning multimedia is made, so the conversion level of achievement on a five scale is used as follows.

Table 6. Conversion Level of Achievement Scale 5

\begin{tabular}{llll}
\hline No & Achievement Rate (\%) & Qualification & Description \\
\hline 1 & $90-100 \%$ & Very good & Very Feasible/ Very Valid/ No Revision Required \\
2 & $80-89 \%$ & Good & Feasible/ Valid/ No Revision Required \\
3 & $65-79 \%$ & Good Enough & Feasible Enough/ Valid Enough/ Revision Required \\
4 & $55-64 \%$ & Less good & Less Feasible/ Less Valid/ Revision Required \\
5 & $0-54 \%$ & Very Not Good & Very Inappropriate/ Very Invalid/ Revision Required \\
\hline
\end{tabular}

(Agung, 2014)

\section{RESULT AND DISCUSSION}

\section{Result}

The design of this learning multimedia uses the Hannafin and Peck model which can be described as follows. The first stage is a needs assessment which consists of instructional problem analysis, audience analysis, goal analysis, and instructional setting analysis. In the problem analysis, interviews were conducted with the class IV-A teacher and it was known that the obstacles during online learning are students tend to get bored quickly and not focus on learning, teachers find it difficult to hold meetings through google meet or zoom meetings with students because not all students have personal smartphones, students tend to rely on their parent's smartphones to get information. The learning resources used so far are from books and learning media such as videos of learning materials. In the audience analysis through observation, interviews with class teachers, and giving questionnaires to students it is known that in class IV-A there are 45 students and all students have smartphones (personal and parents smartphones) that can be used for online learning, there are also three students who have laptops in the class. All students can operate or use smartphones well. Class IV-A teachers also have smartphones and can use laptops for the learning process. From the results of giving questionnaires to students, it can also be seen that $55.6 \%$ of students experience quota or network constraints when online learning, $60 \%$ of students feel that online learning is boring, $64.4 \%$ of students feel that learning mathematics is difficult, $66.7 \%$ of students feel that the circumference and area of flat shapes in textbooks and worksheets is difficult to understand. In addition, from student responses it can be seen that $28.9 \%$ of students find it easier to understand the circumference and area of flat shapes when explained using learning media, $57.8 \%$ of students feel that the learning media used during online learning is less varied, $37.8 \%$ students feel more interested participating learning when using educational game media, during online learning $24.4 \%$ of students learn by doing homework or assignments, and $42.2 \%$ of students doing online learning in the morning. In goal analysis, interviews and discussions were conducted with the class IV-A teacher which resulted in learning objectives for the circumference and area of flat shapes are generated from KD as well as indicators in the teacher's book and student's book. In the instructional setting analysis through observation and interviews with grade IV-A teachers at SD Negeri 3 Sesetan, it was found that during the Covid-19 pandemic, learning was carried out fully online. However, once a week parents of students come to school in turns to collect the results of student work while still complying with the applicable health protocols.

The second stage is the design which consists of several stages, namely 1) Determining the software used in making learning multimedia, namely RPG Maker MV and Adobe Photoshop CC 2019, while the 
hardware used is laptops and smartphones. 2) Create outline content which consists of a) Making material about the circumference and area of flat shapes for fourth-grade elementary school students such as square, rectangle, and triangle shapes. b) Create a character in the game consisting of 2 main players and 16 NPCs (Non-Player Characters). c) Determine the game flow which consists of 3 levels that is level 1 on city maps, level 2 on village maps, and level 3 on beach maps. d) Determine the title of the game namely KeLuAr. 3) Create a flowchart to make it easier to create a game flow from the start to the exit. 4) Create a storyboard that contains an overview of the background, audio, navigation, characters, maps, and materials used in the development of learning multimedia. 5) Develop lesson plans to design the implementation of learning following the use of learning multimedia so that it is structured and systematic. 6) Develop a product assessment instrument to produce a questionnaire that will be used in the product feasibility test.
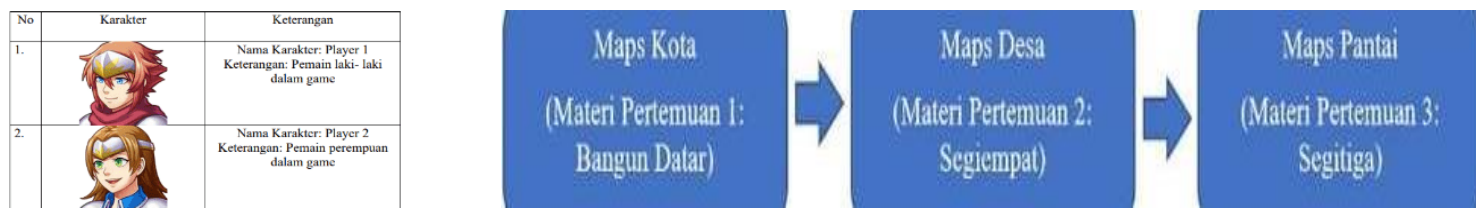

Pictures 1. Characters and Game Flow


Pictures 2. Flowchart and Storyboard

The third stage is development and implementation. Development begins with designing the product start page using Adobe Photoshop CC 2019. The start page or menu consists of the game title, new button, continue button, options button. Followed by mapping or making maps using the RPG Maker MV application which is based on storyboards, for this learning multimedia there are 17 maps divided into 3 levels with different missions and materials. Next is databased using which is a collection of various types of data used in making this learning multimedia that is consisting of faces, pictures, side view actors, and tilesets. Then eventing is the process of making events so that the game looks more alive. Events made using RPG Maker MV and the events are given to characters, animations, audio, images, maps, dialogue, and character movement. Furthermore, testing the events that are made to find out whether the events created in the game are as expected when the game is played. Testing was done to find deficiencies or errors that occur when giving events to the game so that improvements can be made. Next is creating a compact disk (CD) design using Adobe Photoshop CC 2019 for the $\mathrm{CD}$ pieces and the $\mathrm{CD}$ holder. On the design of the $\mathrm{CD}$ pieces, there is a game title and the name of the developer. On the front display design of the $\mathrm{CD}$ holder there are game titles, and information about the materials contained in the $\mathrm{CD}$, while for the rearview design there is information on how to use learning multimedia from the installation process until the learning multimedia or games can be used, besides that there is also a developer profile. After the learning multimedia has been developed and the CD design has been created, the result of learning multimedia application file is then packaged in a compact disk to be ready for use.

At the development stage, a feasibility test for learning multimedia products. The material expert test get a percentage score of $90 \%$ with very good qualifications and very feasible. The learning media expert test get a percentage score of $96.7 \%$ with very good qualifications and very feasible. The learning design expert test get a percentage score of $95 \%$ with very good qualifications and very feasible. The individual trials conducted by 3 students of SD Negeri 3 Sesetan get an average percentage score of $96.7 \%$ with very good qualifications and very feasible. The small group trial conducted by 9 students of SD Negeri 3 Sesetan get an average percentage score of $95.6 \%$ with very good qualifications and very feasible. At the implementation stage, field trials were carried out on learning multimedia that had been made by involving all students of class IV-A. After students use learning multimedia then they are given a pretest and posttest to determine the effectiveness of using RPG Maker 
MV based on learning multimedia. However, due to the Covid-19 pandemic, it is not possible to conduct offline learning which can involve many students and can cause crowds. Therefore, the implementation stage was not carried out due to circumstances and conditions that did not allow it. The fourth stage is evaluation and revision which aims to improve, refine and avoid errors in the final product. There are several evaluations from experts during the development of learning multimedia such as at the design stage like the creation of outline content, making the materials, characters, lesson plans, and product assessment instruments. After getting notes, suggestions, and comments from experts, revisions were made so that the RPG Maker MV learning multimedia was considered very feasible or very good for use in the learning process
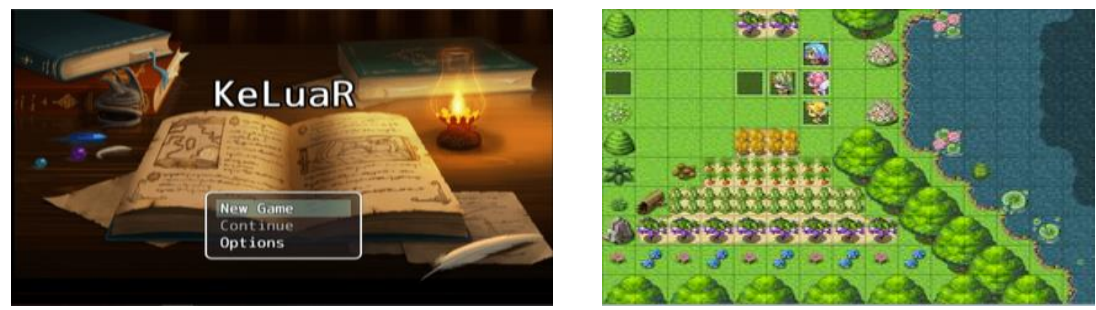

Pictures 3. Start Page Design and Mapping

\section{Discussion}

This learning multimedia has an update for used RPG Maker MV as the base for its development by adjusting to the character of elementary school children who still like to play. Characteristics of elementary school children are like to play so teachers should design learning that uses elements of the game and involves students directly in learning (Dinayusadewi et al., 2020; Fisnani et al., 2020; Subali et al., 2019). Therefore, the development of learning multimedia based on RPG Maker MV produces a games product so that users in this case is elementary school students can be directly involved in the use of learning multimedia material circumference and area of flat shapes (square, rectangle, triangle) and students can learn in a fun way while playing. Multimedia pembelajaran akan membuat siswa lebih termotivasi dalam belajar (Maria et al., 2019; Velan et al., 2015). Selain itu penggunaan multimedia ini juga dapat membantu siswa belajar secara mandiri (Heo \& Toomey, 2020; Komalasari \& Rahmat, 2019). The use of play while learning method succeeded in improving the process and student learning outcomes (Kusuma et al., 2021; Yati et al., 2017). The selection of RPG (Role Play Game) in the development of learning multimedia is based on a survey which states that games with the RPG (Role Play Game) genre are at the first level in Indonesia with a percentage of 46\%, also stated that games with the RPG genre have the advantage that users can control or play directly a character in the game story that has been designed (Samudra \& Djuniadi, 2017). Playing games is very liked by children so that students will be more enthusiastic in learning (Cha \& Seo, 2018; Lauc et al., 2020; Rose et al., 2016).

Based on comments during individual tests and small group trials, it can be seen that this RPG Maker MV learning multimedia is very fun, interesting, and very educational for students to learn about circumference and area of flat shapes. Multimedia learning is very liked by students (Khamparia \& Pandey, 2017; Majid et al., 2012). The game-based learning media is very interesting for students (Bartel \& Hagel, 2014; Emerson et al., 2020; Sunarti et al., 2016). The educational games can increase student's attention, concentration and improve student learning outcomes (Kao, 2020; Su \& Cheng, 2013). The interactive game learning media is very interesting and exciting for students, besides that it can also increase student's interest and motivation in learning and make it easier for students to understand learning material (Su \& Cheng, 2013; Yeh et al., 2017). So, with this RPG Maker MV-based learning multimedia it is hoped that learning will be more fun, interesting, and can increase student's motivation to learn, also can reduce student boredom in learning because now learning is done while playing. The existence of this RPG Maker MV-based learning multimedia is also expected to be well utilized by teachers and students to conduct online learning flexibility. In addition, this research can also be used as a reference in conducting other development research. It is recommended that when conducting development research, it is carried out up to the field trial stage to determine the effectiveness of the products used.

\section{CONCLUSION}

The design of learning multimedia based on RPG Maker MV the circumference and area of flat shapes material for elementary school students with the Hannafin and Peck model is have been declared that the game product was very feasible for use in the learning process based on the results of material expert tests, learning media expert tests, learning design expert tests, individual trials, and small group trials. In addition, this RPG 
Maker MV-based learning multimedia product for elementary school students can be used flexibly when online learning, also can attract student's attention.

\section{REFERENCES}

Abidah, A., Hidaayatullaah, H. N., Simamora, R. M., Fehabutar, D., \& Mutakinati, L. (2020). The Impact of Covid-19 to Indonesian Education and Its Relation to the Philosophy of "Merdeka Belajar." Studies in Philosophy of Science and Education, 1(1), 38-49. https://doi.org/10.46627/sipose.v1i1.9.

Adedoyin, O. B., \& Soykan, E. (2020). Covid-19 Pandemic and Online Learning: The Challenges and Opportunities. Interactive Learning Environments. https://doi.org/10.1080/10494820.2020.1813180.

Agung, A. A. G. (2014). Metodologi Penelitian Pendidikan. Aditya Media.

Bal-Taştan, S., Davoudi, S. M. M., Masalimova, A. R., Bersanov, A. S., Kurbanov, R. A., Boiarchuk, A. V, \& Pavlushin, A. A. (2018). The Impacts of Teacher's Efficacy and Motivation on Student's Academic Achievement in Science Education among Secondary and High School Students. EURASIA Journal of Mathematics, Science and Technology Education, 14(6), 2353-2366. https://doi.org/10.29333/ejmste/89579.

Bartel, A., \& Hagel, G. (2014). Engaging Students with a Mobile Game-Based Learning System in University Education. International Journal of Interactive Mobile Technologies, 8(4), 957- 960. https://doi.org/10.3991/ijim.v8i4.3991.

Burhaein, E. (2017). Aktivitas Fisik Olahraga untuk Pertumbuhan dan Perkembangan Siswa SD. Indonesian Journal of Primary Education, 1(1), 51-58. https://doi.org/10.17509/ijpe.v1i1.7497.

Cha, S. S., \& Seo, B. K. (2018). Smartphone Use and Smartphone Addiction in Middle School Students in Korea: Prevalence, Social Networking Service, and Game Use. Health Psychology Open, 5(1), 1-15. https://doi.org/10.1177/2055102918755046.

Chen, E., \& Li, Z. (2011). On the Application of Multimedia Technology in Foreign Language Teaching and Learning in China's Colleges: Challenges, Problems and Implications. 2011 International Conference on Multimedia Technology, ICMT 2011, 595-597. https://doi.org/10.1109/ICMT.2011.6001903.

Daniels, L. M., \& Gierl, M. J. (2017). The Impact of Immediate Test Score Reporting on University Students' Achievement Emotions in the Context of Computer-Based Multiple-Choice Exams. Learning and Instruction, 52. https://doi.org/10.1016/j.learninstruc.2017.04.001.

Darmaji, Kurniawan, D. A., Astalini, Lumbantoruan, A., \& Samosir, S. C. (2019). Mobile Learning in Higher Education for the Industrial Revolution 4.0: Perception and Response of Physics Practicum. International Journal of Interactive Mobile Technologies (Vol. 13, Issue 9). https://doi.org/10.3991/ijim.v13i09.10948.

Dewi, I. G. A. A. S. S., Sudatha, I. G. W., \& Sukmana, A. I. W. I. Y. (2019). Pengembangan Multimedia Pembelajaran Interaktif Berorientasi Pendidikan Karakter Mata Pelajaran Bahasa Bali. Journal of Education Technology, 3(3), 190. https://doi.org/10.23887/jet.v3i3.21745.

Dinayusadewi, N. P., Ngurah, G., \& Agustika, S. (2020). Development of Augmented Reality Application as a Mathematics Learning Media in Elementary School Geometry Materials. Journal of Education Technology, 4(2), 204-210. https://doi.org/10.23887/jet.v4i2.25372.

Emerson, A., Cloude, E. B., Azevedo, R., \& Lester, J. (2020). Multimodal Learning Analytics for Game-Based Learning. British Journal of Educational Technology, 51(5). https://doi.org/10.1111/bjet.12992.

Fisnani, Y., Utanto, Y., \& Ahmadi, F. (2020). The Development of E-Module for Batik Local Content in Pekalongan Elementary School. Innovative Journal of Curriculum and Educational Technology, 9(1), 40-47. https://doi.org/10.15294/IJCET.V9I1.35592.

Handayani, Hadi, Isbaniah, Burhan, \& Agustin. (2020). Corona Virus Disease 2019. Jurnal Respirologi Indonesia", 40(2). https://doi.org/10.36497/jri.v40i2.101.

Heo, M., \& Toomey, N. (2020). Learning With Multimedia: The Effects of Gender, Type of Multimedia Learning Resources, and Spatial Ability. Computers and Education, 146, 103747. https://doi.org/10.1016/j.compedu.2019.103747.

Indah Septiani, A. nisa N. S., Septiani, I., Rejekiningsih, T., Triyanto, \& Rusnaini. (2020). Development of Interactive Multimedia Learning Courseware to Strengthen Students' Character. European Journal of Educational Research, 9(3), 1267-1279. https://doi.org/10.12973/eu-jer.9.3.1267.

Jogezai, N. A., Baloch, F. A., Jaffar, M., Shah, T., Khilji, G. K., \& Bashir, S. (2021). Teachers' Attitudes towards Social Media (SM) Use in Online Learning Amid the Covid-19 Pandemic: The Effects of SM Use by Teachers and Religious Scholars During Physical Distancing. Heliyon, 7(4). https://doi.org/10.1016/j.heliyon.2021.e06781.

Juwantara, R. A. (2019). Analisis Teori Perkembangan Kognitif Piaget pada Tahap Anak Usia Operasional Konkret 7-12 Tahun dalam Pembelajaran Matematika. Jurnal Ilmiah Pendidikan Guru Madrasah 
Ibtidaiyah, 9(1), 27-34. https://doi.org/10.18592/aladzkapgmi.v9i1.3011.

Kao, C.-W. (2020). The Effect of a Digital Game-Based Learning Task on the Acquisition of the English Article System. System, 95. https://doi.org/10.1016/j.system.2020.102373.

Kassim, M., \& Idris, A. (2018). Multimedia Project on Website Development Using Dreamweaver and Publish Domain among Engineering Students. International E-Journal of Advances in Education, IV(12), 983993.

Khamparia, A., \& Pandey, B. (2017). Impact of Interactive Multimedia in E-Learning Technologies: Role of Multimedia in E-Learning. Enhancing Academic Research with Knowledge Management Principles, April, 199-227. https://doi.org/10.4018/978-1-5225-2489-2.ch007.

Kivunja, C. (2015). Unpacking the Information, Media, and Technology Skills Domain of the New Learning Paradigm. International Journal of Higher Education, 4(1). https://doi.org/10.5430/ijhe.v4n1p166.

Knoop-van Campen, C. A. N., Segers, E., \& Verhoeven, L. (2020). Effects of Audio Support on Multimedia Learning Processes and Outcomes in Students with Dyslexia. Computers and Education, 150(February), 103858. https://doi.org/10.1016/j.compedu.2020.103858.

Komalasari, K., \& Rahmat, R. (2019). Living Values Based Interactive Multimedia in Civic Education Learning. International Journal of Instruction, 12(1), 113-126. https://doi.org/10.29333/iji.2019.1218a.

Kusuma, G. P., Suryapranata, L. K. P., \& Utomo, Y. (2021). Enhancing Historical Learning Using Role-Playing Game on Mobile Platform. Procedia Computer 179. https://doi.org/10.1016/j.procs.2021.01.078.

Lauc, T., Jagodić, G. K., \& Bistrović, J. (2020). Effects of Multimedia Instructional Message on Motivation and Academic Performance of Elementary School Students in Croatia. International Journal of Instruction, 13(4), 491-508. https://doi.org/10.29333/iji.2020.13431a.

Majid, M. S. Z. B. A., Ali, M. M. B. A., Rahim, A. A. B. A., \& Khamis, N. Y. B. (2012). The Development of Technical English Multimedia Interactive Module to Enhance Student Centered Learning (SCL). Procedia - Social and Behavioral Sciences, 67, 345-348. https://doi.org/10.1016/j.sbspro.2012.11.337.

Manurung, \& Panggabean. (2020). Improving Students' Thinking Ability In Physics Using Interactive Multimedia Based Problem Solving. Cakrawala Pendidikan, 39(2), 460-470. https://doi.org/10.21831/cp.v39i2.28205.

Maria, U., Rusilowati, A., \& Hardyanto, W. (2019). Interactive Multimedia Development in the Learning Process of Indonesian Culture Introduction Theme for 5-6 Year Old Children. Journal of Primary Education, 8(3), 344-353. https://journal.unnes.ac.id/sju/index.php/jpe/article/view/27929.

Nugroho, F., \& Iqbal Arrosyad, M. (2020). Moodle Multimedia Development in Web-based Integrative Thematic Learning for Class IV Elementary Students. Cendekiawan, 2(1), 49-63. https://doi.org/10.35438/cendekiawan.v2i1.177.

Pranopik, M. R. (2017). Pengembangan Variasi Latihan Smash Bola Voli. Jurnal Prestasi, 1(1), 31-33. https://doi.org/10.24114/jp.v1i1.6495.

Pratomo, A. (2015). Pengembangan Media Pembelajaran Interaktif Berbasis Web Menggunakan Metode Hannafin dan Peck. Positif, 1(1), 14-28. https://ejurnal.poliban.ac.id/index.php/Positif/article/view/204.

Raja, R., \& Nagasubramani, P. C. (2018). Impact of Modern Technology in Education. Journal of Applied and Advanced Research, 3(S1), 33. https://doi.org/10.21839/jaar.2018.v3is1.165.

Ran, W., Yamamoto, M., \& Xu, S. (2016). Media Multitasking During Political News Consumption: A Relationship with Factual and Subjective Political Knowledge. Computers in Human Behavior, 56. https://doi.org/10.1016/j.chb.2015.12.015.

Ristanti, F. F., \& Arianto, F. (2019). Flash Card Media Utilization to Improve Student Activity and Learning Outcomes of Fauna Distribution Subtopic in Class XI IPS I SMA Xin Zhong Surabaya. Geosfera Indonesia, 4(2), 90. https://doi.org/10.19184/geosi.v4i2.9968.

Riyanto, W. D., \& Gunarhadi, G. (2017). The Effectiveness of Interactive Multimedia in Mathematic Learning: Utilizing Power Points for Students with Learning Disability. IJPTE: International Journal of Pedagogy and Teacher Education, 1(1), 55-63. https://doi.org/10.20961/ijpte.v1i1.8400.

Rose, J. A., O’Meara, J. M., Gerhardt, T. C., \& Williams, M. (2016). Gamification: Using Elements of Video Games to Improve Engagement in an Undergraduate Physics Class. Physics Education, 51(5). https://doi.org/10.1088/0031-9120/51/5/055007.

Rubini, B., Permanasari, A., \& Yuningsih, W. (2018). Learning Multimedia Based on Science Literacy on the Lightning Theme. Journal of Science Learning and Research, 4(2), 89-104. https://doi.org/10.30870/jppi.v4i2.3926.

Samudra, D. G., \& Djuniadi, D. (2017). Implementasi Hack and Slash dalam Sistem Pertarungan Game RPG Joko Tingkir. Edu Komputika Journal, 4(2), 45-52. https://doi.org/10.15294/edukomputika.v4i2.22494.

Saripudin, E., Sari, I., \& Mukhtar, M. (2018). Using Macro Flash Animation Media on Motion Material to 
Improve Learning Achievement for Learning Science in Junior High School. , 4 (1). Journal of Science Research and Learning, 4(1), 68-75. https://doi.org/10.30870/jppi.v4i1.3316.

Shaik Alavudeen, S., Easwaran, V., Iqbal Mir, J., Shahrani, S. M., Ali Aseeri, A., Abdullah Khan, N., Mohammed Almodeer, A., \& Abdullah Asiri, A. (2021). The Influence of Covid-19 Related Psychological and Demographic Variables on the Effectiveness of E-Learning Among Health Care Students in the Southern Region of Saudi Arabia. Saudi Pharmaceutical Journal. https://doi.org/10.1016/j.jsps.2021.05.009.

Sholihah, A. F. (2019). Pengembangan Media Puzzle Berbasis Make a Match pada Pembelajaran Tematik Kelas II di MI At-Taufiq Singaraja Tahun Pelajaran 2018/2019. 1-216.

Su, C.-H., \& Cheng, C.-H. (2013). A Mobile Game-based Insect Learning System for Improving the Learning Achievements. Procedia - Social and Behavioral Sciences, 103. https://doi.org/10.1016/j.sbspro.2013.10.305.

Subali, B., Kumaidi, Aminah, N. S., \& Sumintono, B. (2019). Student Achievement Based on the Use of Scientific Method in the Natural Science Subject in Elementary School. Jurnal Pendidikan IPA Indonesia, 8(1), 39-51. https://doi.org/10.15294/jpii.v8i1.16010.

Sugiyono. (2019). Metode Penelitian dan Pengembangan (M. S. Sofia Yustiyani Suryandari, S.E. (ed.); 4th ed.). Alfabeta.

Sunarti, Rahmawati, S., \& Wardani, S. (2016). Pengembangan Game Petualangan "Si Bolang” sebagai Media Pembelajaran Tematik untuk Meningkatkan Motivasi dan Prestasi Belajar Siswa Kelas V Sekolah Dasar. Jurnal Cakrawala Pendidikan, 5(1), 58-68. https://doi.org/10.21831/cp.v1i1.8365.

Tegeh, I. M., Jampel, I. N., \& Pudjawan, K. (2014). Model Penelitian Pengembangan. Universitas Pendidikan Ganesha.

Tere, T., Bayu Seta, H., Nizar Hidayanto, A., \& Abidin, Z. (2020). Variables Affecting E-Learning Services Quality in Indonesian Higher Education: Students' Perspectives. Journal of Information Technology Education: Research, 19, 259-286. https://doi.org/10.28945/4489.

Velan, G. M., Goergen, S. K., Grimm, J., \& Shulruf, B. (2015). Impact of Interactive e-Learning Modules on Appropriateness of Imaging Referrals: A Multicenter, Randomized, Crossover Study. Journal of the American College of Radiology, 12(11). https://doi.org/10.1016/j.jacr.2015.06.026.

Wardani, K. W., \& Setyadi, D. (2020). Pengembangan Media Pembelajaran Matematika Berbasis Macromedia Flash Materi Luas dan Keliling untuk Meningkatkan Motivasi Belajar Siswa. Scholaria: Jurnal Pendidikan Dan Kebudayaan, 10(1), 73-84. https://doi.org/10.24246/j.js.2020.v10.i1.p73-84.

Wong, G. L. H., Wong, V. W. S., Thompson, A., Jia, J., Hou, J., Lesmana, C. R. A., Susilo, A., Tanaka, Y., Chan, W. K., Gane, E., Ong-Go, A. K., Lim, S. G., Ahn, S. H., Yu, M. L., Piratvisuth, T., \& Chan, H. L. Y. (2020). Management of Patients with Liver Derangement During the Covid-19 Pandemic: An Asia-Pacific Position Statement. The Lancet Gastroenterology and Hepatology, 5(8), 776-787. https://doi.org/10.1016/S2468-1253(20)30190-4.

Yati, Wahyuni, \& Slaeli. (2017). The Effect of Storytelling in a Play Therapy on Anxiety Level in Pre-School Children During Hospitalization in the General Hospital of Buton. Public Health of Indonesia, 3(3), 96101. https://doi.org/10.36685/phi.v3i3.134.

Yeh, Y. T., Hung, H. T., \& Hsu, Y. J. (2017). Digital Game-Based Learning for Improving Students' Academic Achievement, Learning Motivation, and Willingness to Communicate in an English Course. International Congress on Advanced Applied Informatics. https://doi.org/10.1109/IIAI-AAI.2017.40.

Yulia, H. (2020). Online Learning to Prevent the Spread of Pandemic Corona Virus in Indonesia. Eternal (English Teaching Journal), 11(1). https://doi.org/10.26877/eternal.v11i1.6068. 